\title{
FIRST RECORD OF IMPOSEX IN Thais deltoidea (LAMARCK, 1822) (MOLLUSCA, GASTROPODA, THAIDIDAE) IN VITÓRIA, ES, BRAZIL
}

\author{
Mércia Barcellos da Costa $^{1}$; Marcos Antônio Fernandez ${ }^{2}$; Danielle Covre Barbiero ${ }^{1}$; Fernanda Tusholska Vaz \\ de Melo ${ }^{l}$, Mariana Beatriz Paz Otegui ${ }^{l}$ and Brisa Saez Ferreira ${ }^{l}$. \\ ${ }^{1}$ Universidade Federal do Espírito Santo - UFES \\ Centro de Ciências Humanas e Naturais, Departamento de Ciências Biológicas, Laboratório de Malacologia \\ (Av. Marechal Campos, 1468, Maruípe 29040-090, Vitória, ES, Brasil) \\ merciabc@gmail.com \\ ${ }^{2}$ Universidade Estadual do Rio de Janeiro - UERJ \\ Programa de Ecotoxicologia Marinha, Departamento de Oceanografia \\ (Rua São Francisco Xavier, 524, $4^{\circ}$ andar - sala 4018E, Maracanã 20550-013, Rio de Janeiro, RJ, Brasil) \\ hallfz@uerj.br
}

Descriptors: Imposex, Organotins compounds, Antifoulings, Bioindicators, Thais deltoidea.

Descritores: Imposex, Organoestânicos, Antiincrustrantes, Bioindicadores, Thais deltoidea.

One of the human activities that introduce chemical substances in the marine environment is the use of antifouling paints on ships hulls. Many formulations of these paints include biocides like organotins as tributyltin (TBT) or triphenyltin (TPT). The use of the organotin compound TBT as biocides in antifoulings for ship hulls or mariculture structures protection, associated or not to TPT, has demonstrated to cause lethal or sublethal damage in many marine species (FENT, 1996), even at ppt concentrations (ALZIEU, 1998). This toxicity has led to a progressive control of the application of organotin compounds in France, in the United Kingdom, in the USA, in Japan, Australia and New Zeeland and also in Germany, Sweden and Demark since the late eighties (CHAMP, 2000). The use of organotins in antifoulings is to be globally banned by IMO (International Maritime Organization - www.imo.org), but the ban originally scheduled to 2003 has not yet entered in force, because the required number of countries ratifying it was reached only by late 2007 (see References for details).

These compounds are considered a threat to marine life in areas with intense naval activities and can act as endocrine disruptors in marine invertebrates, mainly gastropods (FIORONI; OEHLMANN; STROBEN, 1991; MATTHIESSEN; GIBBS, 1998; AXIAK et al., 2003; GAGNÉ et al., 2003). Mollusks possess only a limited metabolic capacity to eliminate such composites and thus present a great potential of organotin bioaccumulation. Therefore, they are excellent bioindicators of organotin pollution in marine ecosystems. The most common application of mollusks as bioindicators is due to the development of an endocrine disruption syndrome called imposex. This syndrome consists in the imposition of male sexual characters, like penis and vas deferens in females (SMITH, 1981; GIBBS; BRYAN, 1987;
HORIGUSHI et al., 1994; MENSINK et al., 2002). Imposex has been described in more than 170 species of marine gastropods and is caused mainly by TBT, although some species can be affected by TPT (SHI et al., 2005, HORIGUCHI et al., 1997; LIMAVERDE et al., 2007). This selectivity makes the syndrome a good biomarker of organotin exposition in gastropods populations (MATTHIESSEN; GIBBS, 1998) and imposex has been frequently used in monitoring organotin pollution around the world (MORCILLO; PORTE, 1998; AXIAK, et al., 2003; MINCHIN, 2003; SMITH; THAIN; BARRY, 2006).

In Brazil, most of the related research is recent, with studies being developed in Rio de Janeiro state (FERNANDEZ et al., 2002, 2005, 2007; PINHEIRO et al. 2006). Imposex was also widespread in northeastern Brazil, being detected in the states of Ceará, Rio Grande do Norte, Paraíba, Pernambuco, Sergipe, and Bahia and in southern Brazil states of Rio Grande do Sul, Santa Catarina and Paraná (CASTRO et al., 2007a, CASTRO; BENVENUTTI; FILLMANN, 2007b), in all cases with greater intensity close to naval activities as ports or shipyards. The neogastropods species Stramonita haemastoma (Linnaeus, 1767) and Thais rustica (Lamarck, 1822) have been used as bioindicators in all investigations along the Brazilian coast. Preliminary surveys had indicated the occurrence of populations of both these species and Thais deltoidea (Lamarck, 1822), in the coast of Espírito Santo state. Antifouling contamination was studied in Vitória, where Tubarão, a big ore terminal, as well as Vitória Port and some marinas are potential sources of organotin pollution (Fig. 1). This work presents the preliminary results obtained for $T$. deltoidea, a new potential bioindicator of organotin pollution, in which imposex had never been recorded before. 


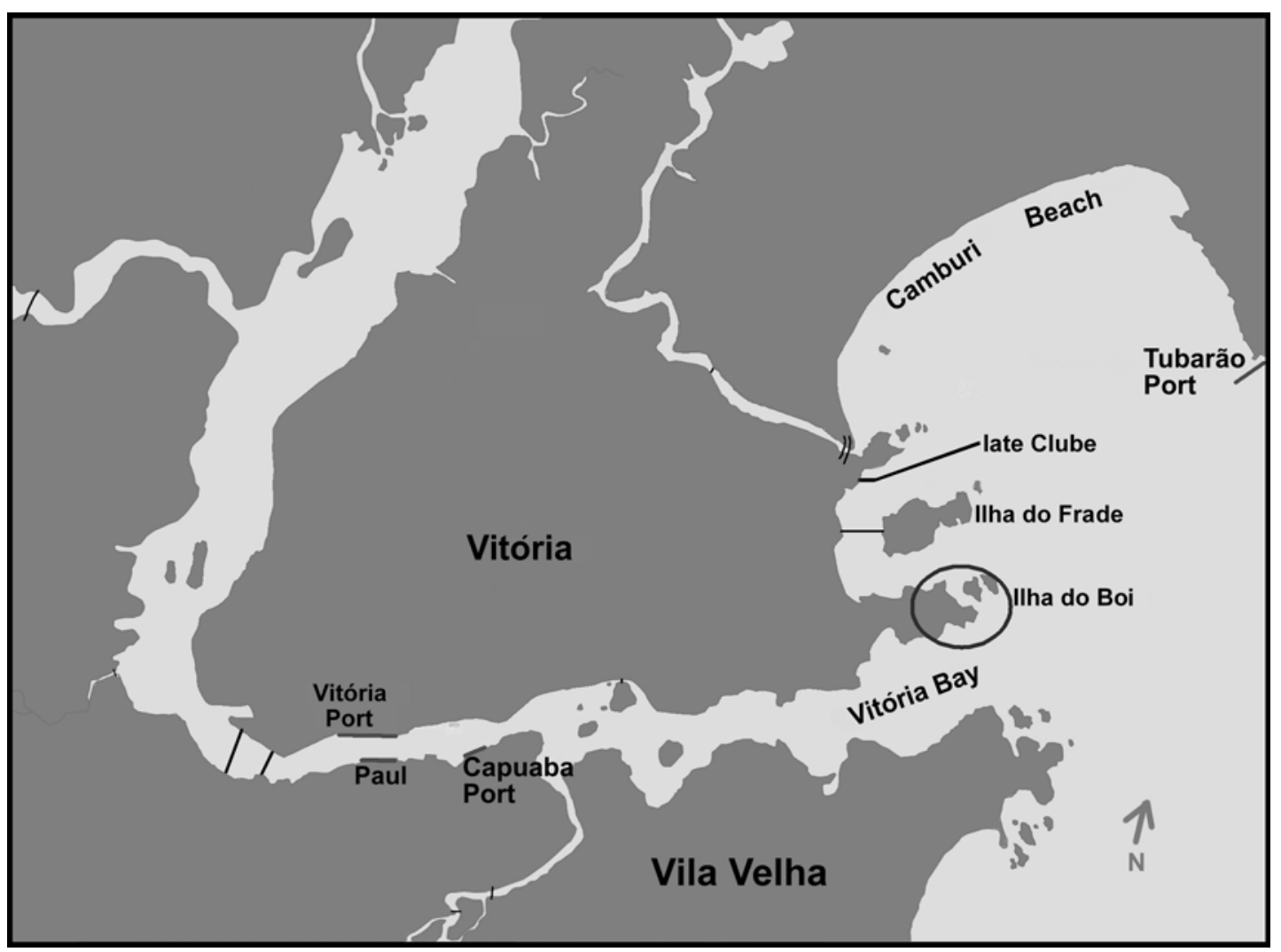

Fig. 1. Location of study area in Vitória Bay-ES, Brazil.

A sample comprising 32 adult individuals, measuring ca. $40 \mathrm{~mm}$ of total shell length was collected at Ilha do Boi $\left(20^{\circ} 18^{\prime} \mathrm{S}\right.$ and $\left.40^{\circ} 16^{\prime} \mathrm{W}\right)$, close to the entrance of Vitoria Port and also near the local Yatch Club, in February, 2006. Animals were kept under aeration and then taken to the Malacology Laboratory, UFES. After narcotization with a solution of $\mathrm{MgCl}_{2} 4 \%$ in distilled water and local sea water $(1: 1)$, the shells were broken in a vice. Sex was determined by the presence of gland capsule, albumen and sperm-ingesting gland in females and the prostate in males which are perfectly differentiated in adult animals. The length of penises in males and in imposexed females was measured with vernier caliper. Imposex development was quantified according to Gibbs and Bryan (1987) and Fernandez et al. (2005), applying the following indexes: imposex percentage in females (I\%); relative penis length index (RPLI); relative penis size index (RPSI) and vas deferens sequence index (VDSI).

The results obtained for $T$. deltoidea collected at Ilha do Boi (Male/Female - 21/11; I\% 90.9; RPSI - 0.41; RPLI - 17.8; VDSI - I-IV), demonstrate the occurrence of imposex in this species, indicating the contamination by organotin compounds in the coast of Espírito Santo.

The morfology of imposex development in T. deltoidea has shown to be very similar to that of other thaidid species previously studied in Brazil. Female penis shape is similar to that of males, and the vas deferens is developed in the same region of the males, beginning at the penis base and extending through the floor of the palial cavity towards the vulva. In sterile females, vas deferens tissue blocked the vulva opening.

The animals at Ilha do Boi showed imposex development, with comparable values for the applied indexes to those observed for $S$. haemastoma in contamined places such as Guanabara Bay and Ribeira Bay in Rio de Janeiro (FERNANDEZ et al., 2002; 2005, PINHEIRO et al, 2006) Fortaleza in Ceará (CASTRO et al., 2007a) and in Vitoria area (unpublished data).

The occurrence of sterility in $T$. deltoidea suggests that this species might even be more sensitive than T. rustica, as the latter has not shown this 
phenomenon when used as biomonitor (CAMILLO et al., 2004; CASTRO et al., 2004; CASTRO et al., 2007a). When directly compared in bioassays with $T$. rustica and S. haemastoma, the results indicated that the first species showed to be less sensitive (CASTRO et al., submitted for publication), what can confirm this observation. In this last study, T. rustica females have taken 90 days of exposure in a small shipyard vicinity to reach $100 \%$ imposex, while $S$. haemastoma females took 30 days; by day 90, this last species female showed sterility, a condition not exhibited by the first species even at the end of the exposure period (120 days).

A certain degree of variability in the intensity of the animals response was observed, probably because of the small sampling. Similar behavior was presented by $T$. rustica in Maceió, Alagoas state, under high hydrodinamics conditions (CAMILLO et al., 2004). As Vitória Bay is a relatively open water body, and possesses a more intense water circulation than an enclosed bay, e.g. Guanabara Bay, this aspect may also have influenced our observation.

The results obtained revealing that $T$. deltoidea might be a useful bioindicator, together with the occurrence of the species on the coast of Espirito Santo would justify further studies.

Although the banishment of organotins as antifoulings is foreseen, the use of this compound is still frequent in many countries. The Brazilian Navy suspended the use of TBT in 2003 and an improvement in imposex development indexes was registered locally, where most Brazilian Navy facilities are installed (FERNANDEZ et al., 2006), but the use of this compound is still allowed in small as well as in big vessels, and biological effects of its application have been detected all along the Brazilian coast. Previously contamined places may still have great amounts of TBT accumulated in the sediments and available to be remobilized for the water column, making these areas liable hotspots for organotin contamination along the years (FERNANDEZ et al., 2005; SMITH et al., 2006). The continuation of studies on biological monitoring using the imposex response will allow checking the antifouling pollution affected areas, to establish the relative degree of contamination among areas and, perhaps, even to verify the ban proper fulfillment, when finally enforced.

\section{AcKNOWLEDGMENTS}

To Dr. Julio César Monteiro (Museu Nacional-Universidade Federal do Rio de Janeiro) for the identification of the species $T$. deltoidea.

\section{REFERENCES}

ALZIEU, C. Tributyltin: case study of a chronic contaminant in the coastal environment. Ocean Coast. Mgmt, v. 40, p. 23-36, 1998.

AXIAK, V.; MICALLEF, D.; MUSCAT, J.; VELLA, A.; MINTOFF, B. Imposex as a biomonitoring tool for marine pollution by tributyltin: some further observations. Environ. Intern., v. 28, p. 43-749, 2003.

CAMILLO, E.; QUADROS, J.; CASTRO, Í. B.; FERNANDEZ, M. A. Imposex in Thais (Stramonita) rustica (Mollusca: Neogastropoda) (Lamarck, 1822) as an indicator of organotin compounds pollution at Maceió coast (Northeastern Brazil). Braz. J. Oceanogr., v. 52, n. 2, p. 101-105, 2004.

CASTRO, I. B.; MEIRELlES, C. A. O.; MATTHEWSCASCON, H.; FERNANDEZ, A. M. Thais (Stramonita) rustica (Lamarck, 1822) (Mollusca: Gastropoda: Thaididae, a potential bioindicator of contamination by organotin northeast Brazil. Braz. J. Ocean., v. 52, n. 2, p. $135-139,2004$.

CASTRO, I. B; ALVES DE LIMA, A. F.; BRAGA, A. R. C.; ROCHA-BARREIRA, C. A. Imposex in two muricid species (Mollusca:Gastropoda) from the northeastern Brazilian Coast. J. Braz. Soc. Ecotoxicol., v. 2, n. 1, p. 81-91, 2007a.

CASTRO, I. B; BENVENUTTI, C. E.; FILlMANN, G. Preliminary appraisal of imposex in areas under the influence of southern Brazilian harbours. J. Braz. Soc. Ecotoxicol., v. 2, n. 1, p. 73-79, $2007 \mathrm{~b}$.

CASTRO, I. B; LIMA, A. F. A.; ROCHA-BARREIRA, C. A; FERNANDEZ, M. A. Imposex development in two muricid species from genus Stramonita: a comparative bioassay study. (submmited for publication Ecotoxicol. Environ. Safet., 2007).

CHAMP, M. A review of organotin regulatory strategies, pending actions, related costs and benefits. Sci. Total Environment, v. 258, p. 21-71, 2000.

FENT, K. Ecotoxicology of organotin compounds. Critic. Rev. Toxicol., v. 26, n. 1, p. 1-117, 1996.

FERNANDEZ, M. A.; LIMAVERDE, A. M.; CASTRO, I. B.; TERRA, A. C.; WAGENER, A. de L. Ocurrence of imposex in Thais haemastoma: evidences of environmental contamination derived from organotion compounds in Rio de Janeiro and Fortaleza, Brasil. Rep. Publ. Health, v. 18, n. 2, p. 463-476, 2002.

FERNANDEZ, M. A.; WAGENER, A. L. R.; LIMAVERDE, A.; SCOFIELD, A. L.; PINHEIRO F. M. RODRIGUES E. Imposex and surface sediment speciation: A combined approach to evaluate organotin contamination in Guanabara Bay, Rio de Janeiro, Brazil. Mar. Environ. Res., v. 59, p. 435-452, 2005.

FERNANDEZ, M. A.; OSTRITZ, F.; REZENDE, A. R; SILVA, S. C.; FOLHA, D. O.; PINHEIRO, F. M. Temporal variability of imposex development in Stramonita haemastoma in Guanabara Bay at a fixed station: results from 1998-2006. In: ENVIRON. HEALTH WORLD CONGRESS, 2006, Santos, SP, Proceedings... 2006, p. 75-79.

FERNANDEZ, M. A.; PINHEIRO, F. M.; QUADROS, J. P.; CAMILLO JR, E. An easy, non-destructive, probabilistic method to evaluate the imposex response of gastropod populations. Mar. Environ. Res., v. 63, p. 41-54, 2007. 
FIORONI, P.; OEHLMANN, J.; STROBEN, E. The pseudohermaphoditism of Prosobranchs: Morfological aspects. Zoollog. Anz., v. 286, n. 1-2, p. 1-26, 1991.

GAGNÉ, F.; BLAISE, C. C.; PELLERIN, J.; PELLETIER, E.; DOUVILLE, M.; GAUTHIER-CLERC, S.; VIGLINO, L. Sex alteration in soft-shell clams (Mya arenaria) in an intertidal zone of the Saint Lawrence river (Quebec, Canada). Comp. Biochem. Physiol., Part C, v. 134, p. 189-198, 2003.

GIBBS, P. E.; BRYAN, G. W. TBT paints and demise of the dog-whelk Nucella lapillus (Gastropoda). Journ. Mar. Biol. Assoc. U.K., v. 68, p. 1482-1487, 1987.

HORIGUCHI, T.; SHIRAISHI, H.; SHIMIZU, M.; MORITA, M. Imposex and organotin compounds in Thais clavigera e T. bronni in Japan. J. Mar. Biol. Assoc. U.K., v. 74, p. 651-669, 1987.

HORIGUCHI, T.; SHIRAISHI, H.; SHIMIZU, M.; MORITA, M. Effects of triphenyltin chloride and five other organotin compounds on the development of imposex in the rock shell, Thais clavigera. Environ. Pollut., v. 95, n.1, p. 85-91, 1997.

INTERNATIONAL MARITIME ORGANIZATION. Marine Antifouling Systems Convention, 2001. www.imo.org Accessed February 2, 2008. Convention joined by 26 countries with $38.13 \%$ of world's merchant fleet by December 31, 2007. Enforcement required 25 countries and $25 \%$ tonnage percent, what happened between July and September, 2007. The complete ban on the application of organotins as antifouling biocides is to be observed one year after the enforcing of the AFS Convention. For further details refer to IMO homepage.

LIMAVERDE, A. M.; WAGENER, A. DE L. R.; FERNANDEZ, M. A.; SCOFIELD, A. L.; COUTINHO, R. Stramonita haemastoma as a bioindicator for organotin contamination in coastal environments. Mar. Env. Res., v. 64, p. 384-398, 2007.

MATTHIESSEN, P.; GIBBS, P. E. Critical appraisal of the evidence for tributyltin-mediated endocrine disruption in mollusks. Environ. Toxicol. Chem., v. 17, n. 1, p. $37-$ 43, 1998.
MENSINK, B. P.; KRALT, H.; VETHAAK, A. D.; TEN HALLERS-TJABBES, C.; KOEMAN, J. H.; VAN HATTUN, B.; BOON, J. P. Imposex induction in laboratory reared juvenile Buccinun undatun by tributyltin (TBT). Environ. Toxicol. Pharmac., v. 11, p. 49-65, 2002.

MINCHIN, D. Monitoring of tributyltin contamination in six marine inlets using biological indicators. Mar. Environ. Health. n. 6, p. 1-15, 2003.

MORCILLO, Y.; PORTE, C. Monitoring of organotin compounds and their in marine molluscs. Trends analyt. Chem., v. 17, n. 2, p. 109-116, 1998.

PINHEIRO, F. M.; FERNANDEZ, M. A.; FRAGOSO, M. R.; QUADROS, J. P.; CAMILLO JR, E.; SANTOS, F. A., 2006. Assessing the impacts of organotin compounds in Ilha Grande Bay (Rio de Janeiro, Brazil); imposex and a multiple source dispersion model. J. Coast. Res., SI 39, p. 1383-1388.

SHI, H. H.; HUANG, C. J.; ZHU, S. X.; YU, X. J.; XIE, W. Y. Generalized system of imposex and reproductive failure in female gastropods of coastal waters in mainland China. Mar. Ecol. Prog. Ser., v. 304, p. 179189, 2005.

SMITH, A. J.; THAIN, J. E.; BARRY, J. Exploring the use of caged Nucella lapillus to monitor changes to TBT hotspot areas: A trial in the River Tyne estuary (UK). Mar. Environ. Res., v. 62, p. 49-163, 2006.

SMITH, B. S. Tributyltin compounds induced male characteristics on female mud snails Nassarius obsoletus = Ilyanassa obsoleta. J. Appl. Toxicol., v. 1, n. 3, p. 141-144, 1981. 